Int. J. Electrochem. Sci., 11 (2016) 4018 - 4026

International Journal of

ELECTROCHEMICAL

SCIENCE

www.electrochemsci.org

Short Communication

\title{
Simultaneous Removal of COD and Ammonia Nitrogen Using a Novel Electro-Oxidation Reactor: A Technical and Economic Feasibility Study
}

\author{
Zhuan Cao ${ }^{1}$, Danni Wen ${ }^{1}$, Hui Chen ${ }^{2}$, Jiade Wang ${ }^{1, *}$ \\ ${ }^{1}$ College of Environment, Zhejiang University of Technology, Hangzhou 310032, China. \\ ${ }^{2}$ Zhejiang Huahai Pharmaceutical Co., Ltd., Taizhou 317000, China \\ *E-mail: jdwang@zjut.edu.cn
}

doi: $10.20964 / 1103100$

Received: 23 January 2016 / Accepted: 8 March 2016 / Published: 1 April 2016

\begin{abstract}
A novel industrial-scale electro-oxidation device was built for simultaneous removal of Chemical Oxygen Demand (COD) and ammonia nitrogen in wastewater. The specific currents had a strong effect on removal rate and total current efficiency. At a specific current of $1440 \mathrm{~A} / \mathrm{m}^{3}$ and electrolysis time of 40min, the concentrations of COD and ammonia nitrogen in effluent decreased from 128.75 $\mathrm{mg} / \mathrm{L}$ and $69.18 \mathrm{mg} / \mathrm{L}$ to $50.0 \mathrm{mg} / \mathrm{L}$ and $5.0 \mathrm{mg} / \mathrm{L}$, respectively. The stepping control for the specific current is useful for saving energy, and total current efficiency increased from $57.61 \%$ to $69.05 \%$ in response to use this stepping control model. The energy consumption was $4.34 \mathrm{kWh} / \mathrm{m}^{3}$, the total operation cost for one ton of effluent was about $\$ 0.574$ and the specific capital cost was $\$ 420 / \mathrm{m}^{3} / \mathrm{d}$. These findings indicate that the electro-oxidation process is capable of simultaneously decomposing refractory organics and ammonia nitrogen in wastewater.
\end{abstract}

Keywords: Electro-oxidation; Plunger flow electrochemical reactor; Ammonia nitrogen; Economic feasibility

\section{$\underline{\text { FULL TEXT }}$}

(C) 2016 The Authors. Published by ESG (www.electrochemsci.org). This article is an open access article distributed under the terms and conditions of the Creative Commons Attribution license (http://creativecommons.org/licenses/by/4.0/). 